\title{
Food allergy and anaphylaxis - 2055: Slow specific oral tolerance induction in children with hen's egg allergy. 3-days on / 4 days off schedule
}

\author{
Kentaro Mikami ${ }^{*}$, Norifumi Ogawa, Norifumi Ogawa², Sho Mimura³ ${ }^{3}$ Akihiro Oshiba ${ }^{4}$, Takeshi Noma $^{2}$ \\ From 2nd WAO International Scientific Conference (WISC 2012) \\ Hyderabad, India. 6-9 December 2012
}

\section{Background}

Specific oral tolerance induction (SOTI) therapy has been used for treat children with food allergy. Patients usually intake food allergens every day in slow-SOTI protocol, but other protocols have not yet been evaluated.

\section{Objective}

The aim of this study is to evaluate the efficacy of SOTI with 3-days on/4-days off schedule per one week for children with hen's egg allergy.

\section{Methods}

Seven children aged 9 months to 6.6 years (median 1.7 years) with hen's egg allergy were performed open oral food challenge tests with boiled hen's egg to define the threshold dose. Subjects underwent SOTI in which they intake boiled hen's egg at home 3 days every week. The dose was increased every 1 to 2 weeks from approximately one fourth of the threshold dose to $60 \mathrm{~g}$. Clinical response and immunologic changes before and after SOTI were evaluated.

\section{Results}

Six of 7 subjects $(85.7 \%)$ could intake higher doses of boiled egg more than the threshold doses. It took 30 to 121 days (median 51 days). Serum total immunoglobulin $\mathrm{E}$ (IgE) changed from $297 \mathrm{IU} / \mathrm{ml}$ (mean of six patients) to $294 \mathrm{IU} / \mathrm{ml}$, egg white-specific immunoglobulin E (sIgE) increased from $10.1 \mathrm{UA} / \mathrm{ml}$ to $16.1 \mathrm{UA} / \mathrm{ml}$, ovomucoid sIgE increased from $4.2 \mathrm{UA} / \mathrm{ml}$ to $6.7 \mathrm{UA} / \mathrm{ml}$, peripheral eosinophils counts decreased from $550 / \mu \mathrm{l}$ to $472 \mu / 1$, and

'Department of Pediatrics, Chiba Aiyukai Memorial Hospital, Nagareyama, Japan

Full list of author information is available at the end of the article wheal size in skin prick test decreased from $4.4 \mathrm{~mm}$ (mean diamiter) to $2.7 \mathrm{~mm}$ after SOTI.

\section{Conclusions}

Three-days on/4-days off schedule in slow SOTI is comparable to everyday schedule for patients with hen's egg allergy.

\section{Author details}

${ }^{1}$ Department of Pediatrics, Chiba Aiyukai Memorial Hospital, Nagareyama, Japan. ${ }^{2}$ Department of Pediatrics, Kitasato University School of Medicine, Sagamihara, Japan. ${ }^{3}$ Department of Pediatrics, Kawaguchi Municipal Medical Center, Kawaguchi, Japan. ${ }^{4}$ Department of Pediatrics, Tokyo Kousei-Nenkin Hospital, Tokyo, Japan.

Published: 23 April 2013

\section{doi:10.1186/1939-4551-6-S1-P138}

Cite this article as: Mikami et al:: Food allergy and anaphylaxis - 2055: Slow specific oral tolerance induction in children with hen's egg allergy. 3-days on / 4 days off schedule. World Allergy Organization Journal 2013 6(Suppl 1):P138

Submit your next manuscript to BioMed Central and take full advantage of:

- Convenient online submission

- Thorough peer review

- No space constraints or color figure charges

- Immediate publication on acceptance

- Inclusion in PubMed, CAS, Scopus and Google Scholar

- Research which is freely available for redistribution

\section{() Biomed Central}

